\title{
Gastric Fistula
}

National Cancer Institute

\section{Source}

National Cancer Institute. Gastric Fistula. NCI Thesaurus. Code C79595.

An abnormal communication between the stomach and another org an or anatomic site. 